\section{Kustamonu Eğitim Dergisi Kastamonu Education Journal}

Ocak 2019 Cilt:27 Sayı:1

kefdergi.kastamonu.edu.tr
Başvuru Tarihi/Received: 03.02.2018

Kabul Tarihi/Accepted: 17.05 .2018

DOI: $10.24106 /$ kefdergi.2637

\title{
Öğretmen Yapımı Sosyal Bilgiler Dersi Sınav Sorularının Yenilenmiş Bloom Taksonomisine Göre İncelenmesi'
}

\section{An Investigation on The Teacher-Made Social Studies Course Exam Questions in Terms of Revised Bloom's Taxonomy ${ }^{1}$}

\author{
Mehmet UYMAZ², Hüseyin ÇALIŞKAN ${ }^{3}$
}

\section{Öz}

Araştırmanın amacı, sosyal bilgiler öğretmenlerinin sınavlarda sordukları soruları Yenilenmiş Bloom Taksonomisi basamaklarına göre analiz etmektir. Araştırma, nitel bir araştırma olarak tasarlanmış ve betimsel tarama modeli kullanılarak gerçekleştirilmiştir. Araştırma grubunu Sakarya ilinde görev yapan 32 sosyal bilgiler öğretmeni oluşturmuştur. Araştrrmada "Bilişsel Süreç ve Bilgi Boyutu Soru İnceleme Formu" veri toplama aracı olarak kullanılmıştır. Araştırmada, öğretmenlerin sınav sorularının Yenilenmiş Bloom Taksonomisinin bilişsel süreç ve bilgi boyutlarının hangi basamağına karşılık geldiğinin belirlenmesi amacıyla yapılan analizler sonucunda, soruların bilişsel seviyelerinin çoğunlukla hatılama ve anlama basamaklarına karşılık geldiği, bilgi boyutu seviyesinin ise yüksek oranda olgusal bilgi boyutunda olduğu sonucuna ulaşılmıştır.

Anahtar Kelimeler: Sosyal bilgiler dersi, sınav soruları, yenilenmiş bloom taksonomisi.

\section{Abstract}

The aim of this study is to analyze the social studies teachers' exam questions in terms of revised bloom taxonomy. The study is designed as a qualitative research and it is carried out using the descriptive survey model. The study group consisted of 32 social studies teachers working in Sakarya province. In the study, "The Cognitive Process Dimension and The Knowledge Dimension Questions Analysis Form" was used as a data collection tool. As a result of analysis related to the cognitive process dimension and the knowledge dimension of Revised Bloom's Taxonomy, the questions, asked in the exams by the teachers, were found to be related to remembering and understanding in terms of the cognitive process dimension, and factual knowledge in terms of knowledge dimension of Revised Bloom's Taxonomy.

Keywords: Social studies courses, exam questions, revised bloom's taxonomy

1. Bu çalışma, "Öğretmen Yapımı Sosyal Bilgiler Dersi Sınav Sorularının Soru Türleri, Kapsam Geçerliği ve Yenilenmiş Bloom Taksonomisine Göre İncelenmesi” adlı tezin bir bölümünden alınarak hazırlanmış ve Mayıs 2017'de gerçekleştirilen Uluslara-rası Sosyal Bilgiler Eğitimi Sempozyumu (IV)'nda sözlü bildiri olarak sunulmuştur. 2. Sakarya Üniversitesi, Sosyal Bilimler Enstitüsü, Sakarya, Türkiye; https://orcid.org/0000-0001-8445-6627

3. Sakarya Üniversitesi, Eğitim Fakültesi, Türkçe ve Sosyal Bilimler Eğitimi Bölümü, Sakarya, Türkiye; https://orcid.org/0000-0001-6849-1318

Atıf / Citation: Uymaz, M., \& Çalışkan, H. (2019). Öğretmen Yapımı sosyal bilgiler dersi sınav sorularının yenilenmiş Bloom Taksonomisine göre incelenmesi. Kastamonu Education Journal, 27(1), 331-346. doi:10.24106/kefdergi.2637 


\section{Extended Abstract}

The achievements involved in the curriculum are directly related to the level of questions asked by learners to learn correctly and thoroughly. There are many classification systems developed to classify the learning objectives (Büyükalan, 2007). The approach most commonly used in classifying the learning objectives is the Bloom Taxonomy, developed by S. Benjamin Bloom, cognitive domain steps including knowledge, understanding, applying, analysis, synthesis and evaluation (Bloom, 1956; Linn ve Gronlund, 1995; Lipscomb, 2001). In the light of developments in learning psychology, teaching methods and assessment of information about contemporary cognitive classification, there emerged a need to update the ideas of Bloom (Anderson ve diğerleri, 2001; Krathwohl, 2002). Bloom's six major categories from the updated first classification of significant changes to the noun into action. On the other hand, the mentioned sub-categories to the whole of "cognitive processes" characterization are reviewed. In addition, Bloom's original classification of dimensionality has been rearranged into two dimensions. One of these dimensions is treated as "cognitive processes" and the other as "information type" (Amer, 2006; Krathwohl, 2002). In the cognitive process dimension, there are mental actions called remembering, understanding, applying, analyzing, evaluating and creating.

In the information dimension, there are four categories: factual, conceptual, transactional and meta-cognitive information. These categories are thought to rank correctly from the context to abstract. It is important to prepare question according to revised bloom's taxonomy so that students can improve problem solving, research, higher order thinking skills such as critical and creative thinking. It is important to evaluate the questions that are used in the social studies class tests, whether the students have knowledge about the subject or they are able to think at the high level.

The study was designed as a qualitative research and was carried out using the descriptive survey model. The study group consisted of 32 social studies teachers working in 30 different secondary schools in Adapazarı, Akyazı, Arifiye, Hendek and Ferizli districts of Sakarya province. The "Cognitive Process and Knowledge Size Questionnaire Form" was used to examine the exam questions within the scope of the research in terms of the Cognitive Process and Knowledge Dimension steps of the Revised Bloom's Taxonomy the exam questions included in the research were classified according to the Cognitive Process Dimension and Information Dimension Steps of the Revised Bloom's Taxonomy. After the questions on the examination papers were analyzed by the researcher according to the taxonomic levels, researchers were diversified in order to increase the reliability and validity of the research.

In the 2013-2014 academic year, social studies teachers preferred mostly $(\% 54,92)$ the questions related to remembering and understanding $(\% 38,75)$ in terms of the cognitive dimension of the Revised Bloom's Taxonomy. However, social studies teachers preferred slightly the questions related to analyzing $(\% 3,45)$, applying $(\% 2,75)$ and evaluating $(\%, 13)$. On the other hand, the findings of the research show that teachers did not used the questions related to creating in terms of the cognitive dimension of the Revised Bloom's Taxonomy. According to the analyzes made on the knowledge dimension of the Revised Bloom's Taxonomy, teachers used the questions intensively $(\% 80,38)$ related to factual knowledge. However, teachers used slightly related to conceptual knowledge $(\% 15,43)$, procedural knowledge $(\% 4,08)$ and metacognitive knowledge $(\% 0,12)$.

An important result of the study is that the questions asked by the social studies teachers often related to remembering and understanding in terms of the Revised Bloom's Taxonomy. On the contrary, it was determined that teachers did not used the questions related to creating. These results show that social studies teachers preferred the questions related to lower cognitive level. However, results show that the number of the questions of higher cognitive level was low.

As a result of the analysis of the questions asked by the teachers about the social studies courses examinations in terms of the Knowledge Dimension steps of the Revised Bloom Taxonomy, it was determined that the teachers preferred the questions at the level of factual knowledge very high $(80,38 \%)$. Secondly, it was found that the teachers use very few of the questions that correspond to the conceptual knowledge, the corresponding questions, and the operational and metacognitive dimension. In this context, it can be said that teachers often used questions at the lower level of knowledge in examinations, they did not sufficiently use the questions in the upper level knowledge dimension.

Teachers to know the steps in the taxonomy, to ask not only the lower level but also the questions corresponding to the higher level steps and to plan a process appropriate to the curriculum; It is important for students to contribute to the cognitive development, to become individuals with advanced critical and creative thinking, and to apply the knowledge, skills and values they have acquired in their daily lives. 


\section{Giriş}

Bilgi çağının yaşandığı günümüzde eğitim sisteminin amacı bilgiyi öğrenciye doğrudan aktarmak değil, bilgiye öğrencilerin kendilerinin ulaşmalarını sağlamaktı (Kaptan, 1999). Eğitim kurumlarının etkili olabilmesi için, okullardaki eğitim öğretim etkinliklerinin bir hedef dâhilinde ve planlı olarak yürütülmesi gerekmektedir. Bu etkinliklerin amaçlı ve planlı bir şekilde yürütülmesindeki temel unsur ise hedeflerdir (Anderson, Krathwohl, Airisian, Cruikshank, Mayer, Pintrich, Raths, Wittrock, 2001).

Bütün eğitim faaliyetlerinde planlı hedefler ve davranışlar bulunmaktadır. Dersler için belirlenen bu hedefler ve davranışlar eğitim-öğretim süreci boyunca öğrencilere kazandırılmaya çalışılmaktadır (işman, 2000). Öğrencilerin dersler sonunda hedeflenen kazanımlara ulaşıp ulaşmadığını ve aynı hedefler çerçevesinde gelişim gösterip gösteremediklerini gözlemleyebilmek için ölçme ve değerlendirmeden yararlanılmaktadır (Balta, 2006). Programlar yapılandırmacı yaklaşım temelinde yapılandırıldığından bireyin, öğrenme-öğretme süreci içerisinde hem zihinsel hem de fiziksel olarak öğrenmeye aktif bir şekilde katılmasını gerektirir (Erdem ve Demirel, 2002). Öğrenme, öğrenenin düşünmeye açık olduğunda ve karşılaşılan sorulara cevaplar bulmaya çalıştı̆̆ anlarda daha etkili gerçekleşmektedir. Ancak bu şekilde kalıcı ve anlamlı öğrenmelerin oluşacağı da bir gerçektir. Öğrencilerin zihinsel süreçlerini harekete geçirebilmek ve içinde bulunulan durumla ilgili gerekli sorgulamaları yaptırabilmek için soru sorma çok önemli bir davranış olarak karşımıza çıkmaktadır (Çalışkan, 2011).

Öğretim programında yer alan kazanımları öğrencilerin doğru ve eksiksiz bir şekilde öğrenebilmeleri ve öğrenilenleri ne oranda kazandıklarının tespiti, sorulan soruların düzeyi ile doğrudan ilişkilidir. Öğrencilerin bilişsel alanlarda başarılarını belirlemek amacıyla öğretmenlerin sordukları soruların düzeylerini belirlemek için geliştirilen birçok sınıflandırma sistemi bulunmaktadır (Büyükalan, 2007). Ancak öğrenme amaçlarının ve bu amaçların ölçme ve değerlendirilmesinde kullanılan soru düzeylerinin sınıflandırılmasında en çok faydalanılan yaklaşım S. Benjamin Bloom tarafindan geliştirilen ve Bloom Taksonomisi olarak isimlendirilen; bilgi, kavrama, uygulama, analiz, sentez ve değerlendirme basamaklarını içeren bilişsel alan basamaklarıdır (Bloom, 1956; Linn ve Gronlund, 1995; Lipscomb, 2001).

Bloom ve arkadaşları tarafindan 1956 yılında yayınlanan bilişsel alan sınıflamasının birçok ülkede yürütülen ölçme-değerlendirme ve öğretim programı geliştirme çalışmalarına önemli katkılarının olduğu vurgulansa da, bazı sınırlılıklarının olduğu dile getirilmiştir. Dünyadaki gelişmeler ışığında, özellikle gelişim ve öğrenme psikolojisi, öğretim yöntem ve ölçme-değerlendirme ile ilgili çağdaş bilgilerin bu sınıflamayla birleştirilmesi ihtiyacı doğduğundan orijinal bilişsel alan sınıflaması 45 yıl sonra "Bloom"un meslektaşları tarafindan güncellenmiştir (Anderson ve diğerleri, 2001; Krathwohl, 2002).

Güncellenmiş sınıflamada yapılan önemli değişikliklerden birincisi Bloom'un alt ana kategorisinin isim halinden eylem haline dönüştürülmesidir. Diğer taraftan sözü edilen bu alt kategorilerin bütününe "bilişsel süreçler" nitelemesi yapılmıştır. Anderson ve diğerleri (2001), hedef kavramını tanımlarken davranış sözcüğünün seçilmesinin sonraki süreçlerde bir takım yanlış anlaşılmalara yol açtı̆ını ve bu yanlış anlaşılmaları kısmen ortadan kaldırmak için "davranış" sözcüğü yerine "bilişsel süreç" ifadesini kullandıklarını vurgulamışlardır. Güncellenmiş sınıflamada yapılan diğer önemli değişiklik sentez/yaratmak ve değerlendirme/değerlendirmek kategorilerinin aşamalı sınıflanma düzeylerinin yer değiştirmesidir (Amer, 2006; Krathwohl, 2002). Ayrıca Bloom'un orijinal sınıflamasındaki tek boyutluluk iki boyut olarak yeniden düzenlenmiştir. Bu boyutlardan biri "bilişsel süreçler" diğeri ise "bilgi türü" olarak ele alınmıştir. Bilişsel süreç boyutunda hatılamak, anlamak, uygulamak, analiz etmek, değerlendirmek ve yaratmak olarak adlandırılan zihinsel eylemler yer almaktadır. Bilgi boyutunda ise olgusal, kavramsal, işlemsel ve üst bilişsel bilgi olmak üzere dört kategori bulunmaktadır. Bu kategorilerin somuttan (olgusal) soyuta (üst bilişsel) doğru sıralandığı düşünülmektedir (Anderson ve diğerleri, 2001).

Bilgi boyutundaki dört temel tür eğitimcilere, neleri öğreteceklerini belirlemede yardımcı olabilir. Bunlar, eğitim hedefleri ile ilgili olarak orta derece özelleştirilmiş bir durumu ortaya koymaktadırlar. Bu yönden düşünüldüğünde genellik derecesi onların bütün sınıflara ve konu alanlarına uygulanabilmesine izin vermektedir (Özçelik, 2010). Bilişsel süreç boyutunda ise zihinsel etkinliklere dayanan ve birbirini izleyen basamaklar söz konusudur. Bilişsel süreç öğretim programında yer alan kazanımların eylem boyutunu ifade etmektedir (Çepni ve diğerleri, 2003). Bilişsel süreçler öğrenci öğrenmelerinin kalıcılığı ve öğrenilenlerin transferi ile ilgilidir. Öğretimin amacı öğrenilenlerin kalıcılığını sağlamak olduğu zaman hedeflerin hatılama sürecini, transferini artırmak olduğu zaman ise hedeflerin anlama, uygulama, çözümleme, değerlendirme ve yaratma ile ilgili süreçleri kapsaması gerekmektedir. Bu süreçler eğitimcilere eğitim ile ilgili değerlendirmelerini geliştirmelerinde yardımcı olmaktadır (Özçelik, 2010).

Son yıllarda eğitimin tüm kademelerinde öğrencilerin düşünme yeteneklerinin geliştirilmesi ön planda tutulmakta- 
dır. Öğretimin; analiz, sentez, değerlendirme, ilişkilendirme ve soyutlama gibi düşünme becerilerini geliştirecek, konuların kavranmasını sağlayacak ve öğrenilenleri dış dünya ile ilişkilendirecek şekilde düzenlenmesi, eğitim sistemini 21. yüzyıla taşıyacak yeniden yapılanmanın özünü oluşturmaktadır. Öğretmenler, bir konunun öğretilmesinde öğrencinin o konuda tanımlama, sınıflama, uygulama, analiz, sentez ve değerlendirme yapabilmesini amaçlamalıdır. Bu tür öğretimde öğrencinin düşünmeyi öğrenmeden, sadece ezberleme yolu ile analiz, sentez ve değerlendirme gibi düşünsel becerileri ortaya koyması beklenemez (Özden, 2005). Öğretmenler tarafindan hazırlanan ölçme araçlarındaki soruların Yenilenmiş Bloom Taksonomisinin dikkate alınarak hazırlanması, öğrencilerin problem çözme, araştrrma, eleştirel ve yaratıcı düşünme gibi üst düzey düşünme becerilerinin gelişimi açısından önem arz etmektedir.

Yapılan literatür taraması sonucunda öğretmenlerin hazırladıkları sınavlarla ilgili Türkçe, tarih, fen bilgisi, matematik derslerinde çalışmaların yapıldığı belirlenmiştir. Öğretmen yapımı sınavlarla ilgili araştırmalar incelendiğinde araştırmaların Bloom Taksonomisi, soru türleri, kapsam geçerliği ve merkezi sınavlarda sorulan sorular ile öğretmenlerin hazırladıkları soruların karşılaştrııması konuları üzerine yoğunlaştı̆̆ı tespit edilmiştir. Araştırma sonuçlarına bakıldığında, öğretmen yapımı sınavlardaki soruların genelde Bloom Taksonomisinin bilgi ve bilişsel süreç boyutlarındaki basamakların alt düzeylerinde ve çoğunlukla da hatılama düzeyinde olduğu belirlenmiştir (Beskisiz, 2009; Kasar, 2013; Khan ve Inamullah, 2011; Kılıç, 2010; Kılıç, 2012; Tolan, 2011). Öğretmenlerin hatıllama düzeyinde sordukları sorular öğrencinin verilen bilgiyi hatırlamasını ya da tanımasını sağlayacak sorulardır. Öğrencinin bu düzeydeki sorulara cevap verebilmesi için konuyla ilgili önceden sahip olduğu bilgiyi hatırlaması gerekmektedir. Taksonominin alt düzeyine karşlık gelen sorular öğrenme-öğretme sürecinde önemliyken, bu soruların gereğinden fazla kullanımının dezavantajları vardır. Taymaz (1975)'a göre hatılama düzeyindeki soruların hemen unutulması ve bir konuya ait derinlemesine olmayan kaba bilgileri ölçüyor olması bu tür soruların en önemli dezavantajlarıdır. Taksonominin üst düzeyindeki davranışlar, bunlar için önkoşul olan alt düzey davranışlardan daha karmaşık olup, herhangi bir düzeydeki davranışın kazanılması bir alt düzeydeki davranışın kazanılmasına, bu da dönüşümlü olarak sonraki alt düzey davranışın kazanılmasına bağlıdır (Yalın, 2005). Öğretmenlerin sordukları soruların farklı seviyelerde olması, öğrencilerin başarılarını, düşünme becerilerini ve derse olan tutumlarını etkilediği göz önüne alındığında; öğretmenler tarafindan sorulan soruların araştrııması önemli görülmektedir (Akpınar ve Ergin, 2006).

Yapılan literatür taraması sonucunda sosyal bilgiler dersi kapsamında öğretmenler tarafindan hazırlanan sınav sorularının Yenilenmiş Bloom Taksonomisine göre incelendiği çalışmaya rastlanmamıştr. Sosyal bilgiler öğretmenlerinin hazırlamış oldukları sınavlardaki soruların Yenilenmiş Bloom Taksonomisinin bilişsel süreç boyutu ve bilgi boyutunun hangi basamaklarına karşılık geldiğinin betimlenmesi amacıyla hazırlanan çalışmanın alana katkı sağlayacağı düşünülmektedir. Buradan hareketle bu araştrrmada öğretmen yapımı sosyal bilgiler dersi sınavlarında öğretmenlerin sordukları soruların Yenilenmiş Bloom Taksonomisinin hangi basamağına karşılık geldiğinin betimlenmesi ve değerlendirilmesi amaçlanmıştır.

\section{Yöntem}

\section{Araştırma Modeli}

Sosyal bilgiler öğretmenlerinin hazırlamış oldukları sınavlarda sordukları soruların Yenilenmiş Bloom Taksonomisinin hangi basamağına karşılık geldiğinin belirlenmesinin amaçlandığı bu araştırma nitel bir araştırma olarak tasarlanmış ve betimsel tarama modeli kullanılarak gerçekleştirilmiştir. Betimsel tarama modeli, araştrrma problemi ile ilgili mevcut durumu ortaya koymayı, tasvir etmeyi ve problemi anlamayı amaçlayan ve hem nicel hem de nitel araştırmalarda kullanılan modeldir (Arıkan, 2011).

\section{Araştirma Grubu}

Araştırma grubunu 2013-2014 eğitim-öğretim yılında Sakarya ili Adapazarı, Akyazı, Arifiye, Ferizli ve Hendek ilçelerinde bulunan toplam 30 devlet okulunda görev yapan 32 sosyal bilgiler öğretmeni oluşturmuştur. Araştrrma grubunun seçilmesinde amaçlı örnekleme yöntemi kullanılmıştı. Amaçı örnekleme yöntemi genel olarak nitel araştırmalarda kullanılır ve bu tür araştırmalarda elde edilen bulguların evrene genellemesi söz konusu değildir. Bu örnekleme türünde araştırmacı kimleri seçeceği konusunda kendi yargısını kullanır ve araştırmanın amacına en uygun olanları örneklem olarak alır (İşçil, 1973). Bu örnekleme yönteminin avantajı örneklem seçiminde araştrrmacının önceki bilgi ve becerilerini kullanmasıdır (Bailey, 1987). Bu bağlamda daha önce edinilen bilgi ve beceriler çerçevesinde araştırmanın amacına uygun olması ve veri toplamanın kolay olması yönünde amaçlı örnekleme yöntemlerinden kolay ulaşılabilir örnekleme yöntemi seçilmiştir. Nitel araştırmalarda kolay ulaşılabilir durum örneklemesi yaygın bir şekilde kullanılmaktadır. Bu örnekleme yönteminin kullanılması araştırmanın hız kazanmasını sağlamaktadır (Yıldırım ve Şimşek, 2011). 


\section{Veri Toplama Aracı}

Araştırma kapsamındaki sınav sorularının Yenilenmiş Bloom Taksonomisinin Bilişsel Süreç ve Bilgi Boyutu basamakları açısından incelenmesi amacıyla "Bilişsel Süreç ve Bilgi Boyutu Soru İnceleme Formu" kullanılmıştır. Araştırmacı tarafindan bu form Bloom (1956), Çepni ve diğerleri (2003), Büyükalan (2004) ve Çalışkan (2011)'ın çalışmalarından yararlanılarak oluşturulmuş ve Bloom Taksonomisinin bilişsel süreç ve bilgi boyutlarında yer alan basamakların özelliklerini, soru ve kazanım ifadelerini belirten, örnek soruları içeren ve soruların ölçtüğü bilişsel düzeylerin nedenini açıklayan bir şekilde yapılandırılmıştır. Beşinci, altıncı ve yedinci sınıf sosyal bilgiler öğretmenlerinin 2013-2014 eğitim-öğretim yılında öğrencilere uyguladıkları sınav sorularının ölçtüğü bilişsel düzeyler oluşturulan bu form ile tespit edilmiştir.

\section{Verilerin Analizi}

Araştırma kapsamındaki sınav soruları Yenilenmiş Bloom Taksonomisinin Bilişsel Süreç Boyutu ve Bilgi Boyutu basamaklarına göre analiz edilerek sınıflandırılmıştır. Sınav kâğıtlarında bulunan sorular araştırmacı tarafindan taksonominin basamaklarına göre analiz edildikten sonra araştırmanın güvenirlik ve geçerliğini artırmak amacıyla araştrmacı çeşitlemesi yapıımıştı. Araştırmacı çeşitlemesi, aynı araştırmada birden fazla araştırmacının işe koşulduğu çalışmalardır (Patton, 2002; Yıldırım ve Şimşek, 2011). Elde edilen verilerin analizinde bir başka araştırmacıyı kullanma ve ulaşılan sonuçları teyit etme, araştırmanın güvenirliğini artıran unsurlardan biridir (Yıldırım ve Şimşek, 2011). Bu bağlamda araştrmacılarla birlikte, sosyal bilgiler eğitimi ve ölçme ve değerlendirme alanlarında görev yapan ve eğitimde ölçme ve değerlendirme üzerine çalışmalar yapan iki akademisyen tarafindan "Bilişsel Süreç ve Bilgi Boyutu Soru İnceleme Formu" kullanılarak sınav kâğıtlarındaki sorular tek tek analiz edilmiştir. Buradan nitel veri analizinin son aşaması olan bulguların doğrulanması aşamasına geçilmiştir. Bulguların doğrulanması, elde edilen sonuçların denenmesi ve onaylanmasıyla gerçekleştirilebilir (Merriam, 1998). Tüm aşamaların kontrolünden sonra, nitel veri analizi ile elde edilen sonuçların, analize sokulan veri setini temsil düzeyi belirlenebilir (Poggenpoel ve Myburgh, 2003). Bu noktada araştırmacının, bireysel etkisinden arındırımış bir kodlama yapma olasılığı çok düşüktür. Bu durumda farklı kodlayıcılar tarafindan aynı veri setine ilişkin kodlama yapılması ve benzerlik oranı önemlidir. Bu benzerlik oranı aynı zamanda nitel araştırmanın güvenirliğini belirlemektedir. İçsel tutarlılık olarak adlandırılan ve kodlayııılar arasındaki görüş birliği olarak kavramsallaştrılan bu benzerlik Miles ve Huberman modeli olarak anılmaktadır. İçsel tutarılı̆̆ı veren kodlama denetimine göre kodlayıcılar arası görüş birliğinin en az \% 80 olması beklenmektedir (Miles ve Huberman, 1994; Patton, 2002). Bu bağlamda araştrmacılar ve akademisyenler tarafindan ayrı ayrı yapılan analizler daha sonra karşılaştrılımış ve görüş birliğinin \%82,5 olduğu belirlenmiştir. Yapılan karşılaştrmada, soruların Yenilenmiş Bloom Taksonomisinin hangi basamağına karşılık geldiği konusunda görüş birliği sağlanamayan sorular araştırmanın kapsamı dışında tutulmuştur.

\section{Bulgular}

Araştırmadaki analizler neticesinde elde edilen bulgular, araştırmanın amacı bağlamında incelenmiştir.

Öğretmenlerin sosyal bilgiler dersi sınavlarında sordukları soruların Yenilenmiş Bloom Taksonomisinin Bilişsel Süreç Boyutundaki basamaklara göre genel dağılımına ilişkin bulgular Şekil 1'deki grafikte gösterilmektedir.

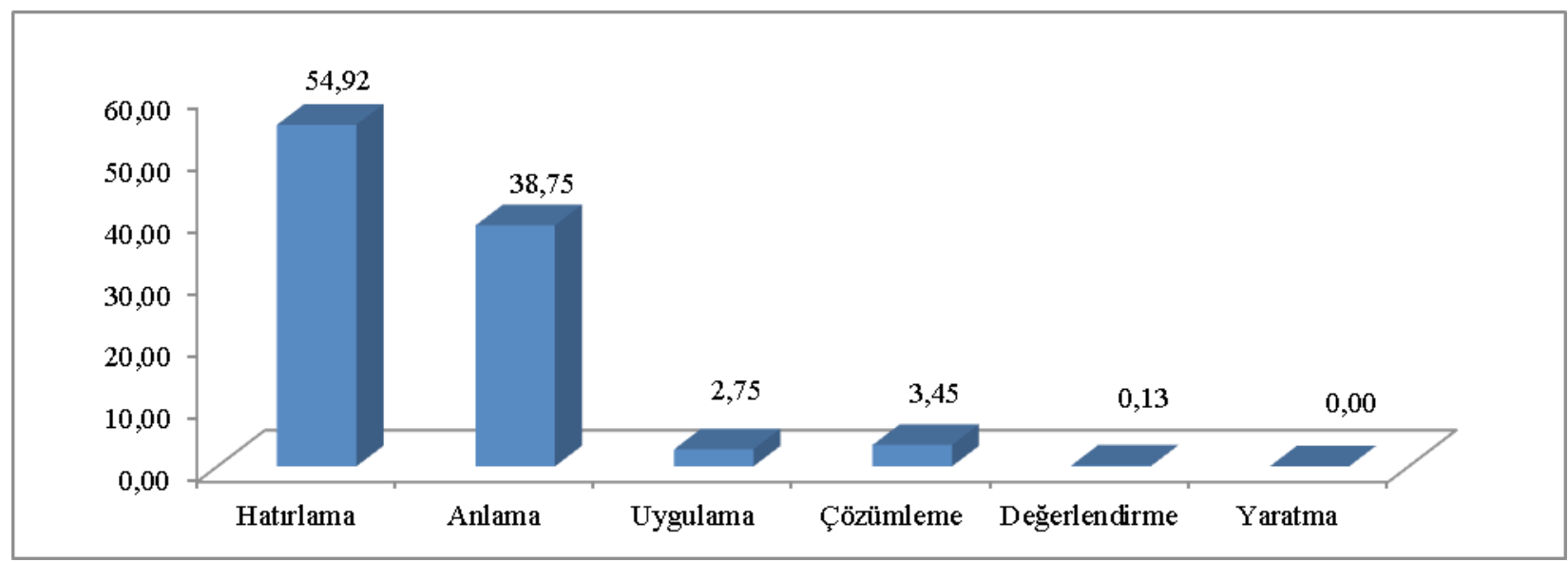

Şekil 1. Sınav Sorularının Yenilenmiş Bloom Taksonomisinin Bilişsel Süreç Boyutundaki Basamaklara Göre Genel Dağılımı

Şekil 1'de verilen grafiğe göre, sosyal bilgiler öğretmenlerinin 2013-2014 eğitim-öğretim yılında öğrencilerine uy- 
guladıkları sınavlarda Yenilenmiş Bloom Taksonomisinin hatırlama basamağındaki sorulara sıklıkla yer verdikleri ve bu basamaktaki soruların tercih edilme oranının \%54,92 olduğu görülmektedir. Ayrıca öğretmenler anlama basamağına karşılık gelen sorulara \%38,75 oranında yer verirken, çözümleme basamağına karşılık gelen sorulara \%3,45, uygulama basamağına karşılık gelen sorulara \%2,75 ve değerlendirme basamağına karşııık gelen sorulara \%0,13 oranında yer vermektedirler. Araştırma kapsamında yapılan analizlerde sosyal bilgiler öğretmenlerinin her üç sınıf düzeyinde de uyguladıkları sınavlarda yaratma basamağı ile ilgili soruya rastlanılmamıştır.

Öğretmenlerin sosyal bilgiler dersi sınavlarında sordukları soruların Yenilenmiş Bloom Taksonomisinin Bilişsel Süreç ve Bilgi Boyutunun hangi basamağına karşılık geldiğinin belirlenmesi için yapılan analizler neticesinde elde edilen bulgular Tablo 1'de gösterilmektedir.

Tablo 1. Sınıf Düzeylerine Göre Sınav Sorularının Yenilenmiş Bloom Taksonomisinin Bilişsel Süreç ve Bilgi Boyutundaki Basamaklarına ilişkin Dağılım

\begin{tabular}{|c|c|c|c|c|c|c|c|c|}
\hline \multirow{2}{*}{$\begin{array}{l}\text { Bilişsel Süreç } \\
\text { Boyutu }\end{array}$} & \multicolumn{2}{|c|}{ 5. Sinif } & \multicolumn{2}{|c|}{ 6. Sinif } & \multicolumn{2}{|c|}{ 7. Sinıf } & \multicolumn{2}{|c|}{ Toplam } \\
\hline & $\mathrm{f}$ & $\%$ & $\mathrm{f}$ & $\%$ & $\mathrm{f}$ & $\%$ & $\mathrm{f}$ & $\%$ \\
\hline Hatıllama & 944 & 57,07 & 1189 & 53,25 & 1178 & 55 & 3311 & 54,92 \\
\hline Hatirlama & 935 & 99,05 & 1189 & 100 & 1164 & 98,81 & 3288 & 99,31 \\
\hline Tanıma & 9 & 0,95 & 0 & 0 & 14 & 1,19 & 23 & 0,69 \\
\hline Anlama & 655 & 39,60 & 874 & 39,14 & 807 & 37,68 & 2336 & 38,75 \\
\hline Yorumlama & 166 & 25,34 & 316 & 36,16 & 210 & 26,02 & 692 & 29,62 \\
\hline Örneklendirme & 71 & 10,84 & 8 & 0,92 & 51 & 6,32 & 130 & 5,57 \\
\hline Sınıflama & 8 & 1,22 & 13 & 1,49 & 26 & 0,99 & 47 & 2,01 \\
\hline Özetleme & 4 & 0,61 & 0 & 0 & 3 & 0,37 & 7 & 0,30 \\
\hline Sonuç Çıkarma & 52 & 7,94 & 140 & 16,02 & 312 & 38,66 & 504 & 21,58 \\
\hline Karşılaştırma & 167 & 25,50 & 194 & 22,20 & 62 & 7,68 & 423 & 18,11 \\
\hline Açıklama & 187 & 28,55 & 203 & 23,23 & 143 & 17,72 & 533 & 22,82 \\
\hline Uygulama & 9 & 0,54 & 95 & 4,25 & 62 & 2,89 & 166 & 2,75 \\
\hline Yapma & 9 & 100 & 90 & 94,74 & 58 & 93,55 & 157 & 94,58 \\
\hline Yararlanma & 0 & 0 & 5 & 5,26 & 4 & 6,45 & 9 & 5,42 \\
\hline Çözümleme & 45 & 2,72 & 72 & 3,22 & 91 & 4,25 & 208 & 3,45 \\
\hline Ayrıştırma & 0 & 0 & 0 & 0 & 15 & 16,48 & 15 & 7,21 \\
\hline Örgütleme & 0 & 0 & 0 & 0 & 6 & 6,59 & 6 & 2,88 \\
\hline İrdeleme & 45 & 100 & 72 & 100 & 69 & 75,82 & 186 & 89,42 \\
\hline Değerlendirme & 1 & 0,06 & 3 & 0,13 & 4 & 0,19 & 8 & 0,13 \\
\hline Denetleme & 1 & 100 & 3 & 100 & 4 & 100 & 8 & 100 \\
\hline Eleştirme & 0 & 0 & 0 & 0 & 0 & 0 & 0 & 0 \\
\hline Yaratma & 0 & 0 & 0 & 0 & 0 & 0 & 0 & 0,00 \\
\hline Oluşturma & 0 & 0 & 0 & 0 & 0 & 0 & 0 & 0 \\
\hline Planlama & 0 & 0 & 0 & 0 & 0 & 0 & 0 & 0 \\
\hline Üretme & 0 & 0 & 0 & 0 & 0 & 0 & 0 & 0 \\
\hline Alt Toplam & 1654 & 100 & 2233 & 100 & 2142 & 100 & 6029 & \\
\hline Bilgi Boyutu & 1654 & 100 & 2233 & 100 & 2142 & 100 & 6029 & \\
\hline Olgusal & 1480 & 89,48 & 1792 & 80,25 & 1574 & 73,48 & 4846 & 80,38 \\
\hline Kavramsal & 148 & 8,95 & 296 & 13,26 & 486 & 22,69 & 930 & 15,43 \\
\hline İşlemsel & 26 & 1,57 & 142 & 6,36 & 78 & 3,64 & 246 & 4,08 \\
\hline Üst Bilişsel & 0 & 0 & 3 & 0,13 & 4 & 0,19 & 7 & 0,12 \\
\hline
\end{tabular}

Tablo 1'de görüldüğü gibi, 2013-2014 eğitim-öğretim yılında sosyal bilgiler öğretmenlerinin beşinci sınıf öğrencilerine uygulamış oldukları sınavlarda Yenilenmiş Bloom Taksonomisinin Bilişsel Süreç Boyutunun hatırlama basamağına karşılık gelen sorulara \%57,07, anlama basamağına karşılık gelen sorulara \%39,60 oranında yer vermektedirler. Diğer yandan öğretmenlerin taksonominin çözümleme basamağına ait soruları \%2,72, uygulama basamağına ait soruları \%0,54 ve değerlendirme basamağına ait soruları \%0,06 oranında tercih ettikleri görülmektedir.

Tablo 1 incelendiğinde, sosyal bilgiler öğretmenlerinin altıncı sınıf düzeyinde yapmış oldukları sınavlarda taksono- 
minin bilişsel süreç boyutunun hatırlama basamağına ait sorulara $\% 53,25$ ve anlama basamağına ait sorulara \%39,14 oranında yer verdikleri görülmektedir. Diğer basamaklarla ilgili sorulara bakıldığında ise uygulama basamağı sorularını \%4,25, çözümleme basamağına ait soruları \%3,22 ve değerlendirme basamağına ait soruları \%0,13 oranında tercih ettikleri görülmektedir.

Tablo 1'e göre sosyal bilgiler öğretmenlerinin yedinci sınıf öğrencilerine uygulamış oldukları sınavlarda taksonominin bilişsel süreç boyutundaki hatırlama basamağına karşılık gelen sorulara \%55,00 ve anlama basamağına karşılık gelen sorulara \%37,68 oranında yer vermektedirler. Bununla birlikte öğretmenlerin çözümleme basamağına ilişkin sorulara \%4,25, uygulama basamağına ilişkin sorulara \%2,89 ve değerlendirme basamağına ilişkin sorulara \%0,19 oranında yer verdikleri görülmektedir.

Öğretmenlerin sosyal bilgiler dersi sınavlarında sordukları soruların Yenilenmiş Bloom Taksonomisinin Bilgi Boyutundaki basamaklara göre dağılımına ilişkin bulgular Şekil 2’deki grafikte gösterilmektedir.

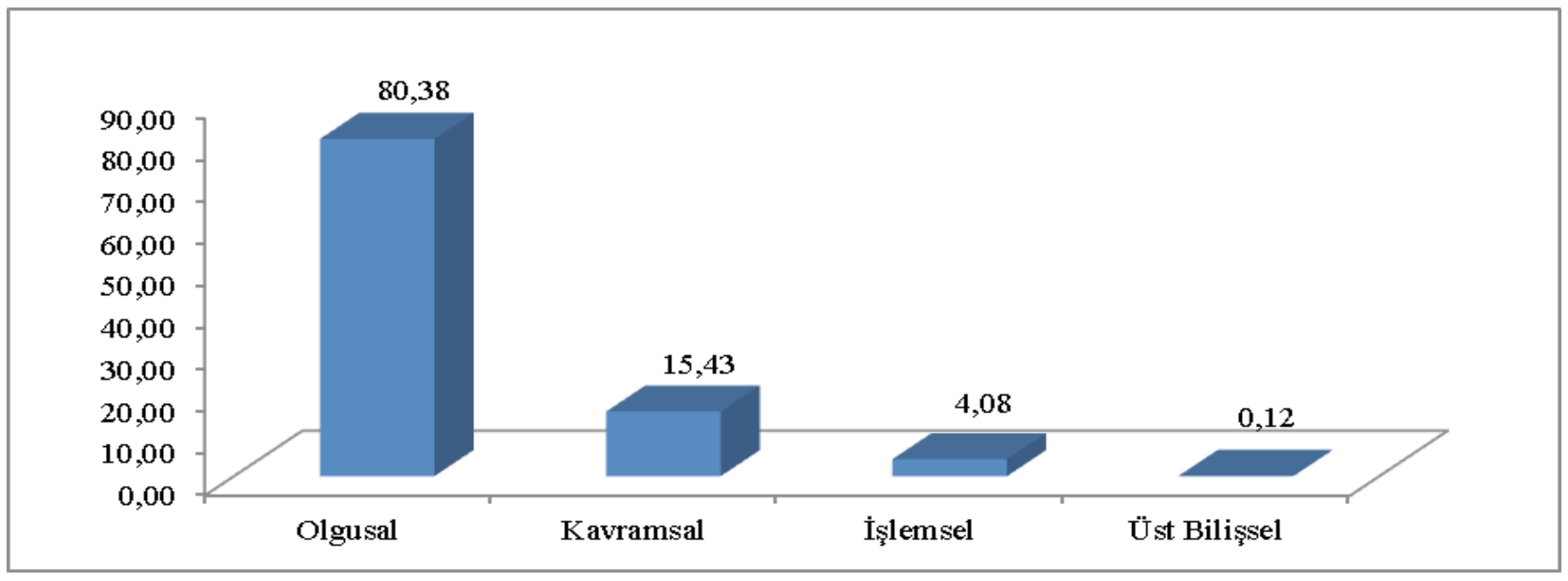

Şekil 2. Sınav Sorularının Yenilenmiş Bloom Taksonomisinin Bilgi Boyutundaki Basamaklara Göre Genel Dağılımı

Şekil 2'deki grafik incelendiğinde 2013-2014 eğitim-öğretim yılında sosyal bilgiler öğretmenlerinin üç sınıf düzeyinde yaptıkları sınavlarda Yenilenmiş Bloom Taksonomisinin Bilgi Boyutunun olgusal bilgi boyutuna karşılık gelen sorulara $\% 80,38$, kavramsal bilgi boyutuna karşılık gelen sorulara \%15,43, işlemsel bilgi boyutuna karşılık gelen sorulara \%4,08 ve üst bilişsel bilgi boyutuna karşılık gelen sorulara \%0,12 oranında yer verdikleri görülmektedir.

Tablo 1'de 2013-2014 eğitim-öğretim yılında sosyal bilgiler öğretmenlerinin beşinci sınıf öğrencilerine uygulamış oldukları sınavlarda Yenilenmiş Bloom Taksonomisinin Bilgi Boyutunun olgusal bilgi boyutuna karşılık gelen sorulara \%89,48, kavramsal bilgi boyutuna karşılık gelen sorulara \%8,95 ve işlemsel bilgi boyutuna karşılık gelen sorulara \%1,57 oranında yer verdikleri, üst bilişsel bilgi boyutuna ise hiç yer vermedikleri görülmektedir.

Tablo 1 incelendiğinde, sosyal bilgiler öğretmenlerinin altıncı sınıf düzeyinde yapmış oldukları sınavlarda taksonominin bilgi boyutunun olgusal bilgi boyutuna ait sorulara \%80,25. kavramsal bilgi boyutuna ait sorulara \%13,26 ve işlemsel bilgi boyutuna ait sorulara \%6,36 oranında yer verdikleri, üst bilişsel bilgi boyutuna ise $\% 0,13$ oranında yer verdikleri görülmektedir.

Tablo 1'de görüldüğü gibi sosyal bilgiler öğretmenlerinin yedinci sınıf öğrencilerine uygulamış oldukları sınavlarda taksonominin bilgi boyutunun olgusal bilgi boyutuyla ilgili sorulara \%73,48 ve kavramsal bilgi boyutuyla ilgili sorulara \%22,69 oranında yer vermektedirler. Diğer yandan öğretmenler işlemsel bilgi boyutuyla ilgili soruları \%3,64 oranında tercih ederlerken üst bilişsel bilgi boyutuyla ilgili sorulara \%0,19 oranında yer vermektedirler.

\section{Tartışma ve Sonuç}

Sosyal bilgiler öğretmenlerinin öğrencilerine uygulamış oldukları sınavlardaki soruların Yenilenmiş Bloom Taksonomisinin basamaklarına göre incelenmesi amacıyla yapılan araştırma sonucunda, araştırma kapsamındaki öğretmenlerin hazırladığı sınav sorularının yarıdan fazlasının $(\% 54,92)$ hatırlama basamağı ile ilgili olduğu belirlenmiştir. Araştırmanın bu sonucu Çalışkan (2011)'ın sosyal bilgiler dersi sınav sorularını incelediği çalışmasında da öğretmenlerin sınavlarda kullandıkları soruların büyük çoğunluğunun hatırlama düzeyinde olduğu sonucu ile örtüşmektedir. Yine Davis ve Tinsley (1967)'in sosyal bilgiler öğretmenlerinin sordukları sorular üzerine yaptıları benzer bir çalışmada öğretmenlerin 
çoğunlukla hatılama düzeyinde sorular sorduğu sonucu araştırmanın sonuçlarını destekler niteliktedir. Ayrıca araştırmanın sonucunda öğretmenlerin anlama basamağına karşılık gelen soruları da yoğun bir şekilde $(\% 38,75)$ kullandıkları tespit edilmiştir. Öğretmenlerin sordukları soruların diğer basamaklara göre dağııımına bakıldığında ise uygulama ve çözümleme basamağına ait sorulara çok az yer verdikleri, değerlendirme basamağındaki sorulara ise yok denecek kadar az sayıda yer verdikleri belirlenmiştir. Öğretmenlerin Yenilenmiş Bloom Taksonomisinin en üst basamağı olan yaratma basamağına ait soruları ise hiç kullanmadıkları belirlenmiştir. Bu sonuçlar, araştırma kapsamındaki öğretmenlerin sosyal bilgiler dersi sınavlarında tercih ettikleri soruların çok büyük çoğunluğunun taksonominin bilişsel süreç boyutunun alt düzeyine karşılık geldiğini, üst düzeye karşlık gelen sorulara ise çok az yer verdiklerini göstermektedir. Koray ve Yaman (2002)'ın fen bilgisi öğretmenlerinin soru sorma becerileriyle ilgili yapttkları benzer bir çalışmada öğretmenlerin çoğunlukla hatılama, anlama ve uygulama seviyesindeki soruları kullandıkları çözümleme, değerlendirme ve yaratma gibi üst düzey seviyedeki sorulara çok az yer verdikleri sonucu bu araştırmanın sonuçlarıyla benzerlik arz etmektedir.

Öğretmenlerin sosyal bilgiler dersi sınavlarında sordukları soruların üç sınıf düzeyindeki genel ortalamasına bakıldığında soruların çok büyük oranda taksonominin hatırlama ve anlama basamaklarına karşılık geldiği bu araştırmanın önemli bir sonucudur. Bu doğrultuda, ders kitaplarındaki sorular üzerine (Celilova, 2006; Koç, 2007; Durukan, 2009), öğretmen yapımı sınavlardaki sorular üzerine (Akpınar 2003; Ayvacı ve Türkdoğan, 2010; Çolak ve Demircioğlu, 2010; Davis, Morse, Rogers ve Tinsley, 1966; Karadüz, 2009; Kılıç, 2010; Koray ve Yaman, 2002), ders sürecinde öğretmenlerin kullandığı sorular üzerine (Baysen, 2006; Can, 2006; Khan ve Inamullah, 2011) gerçekleştirilen çalışmalarda ders kitaplarındaki soruların, öğretmen yapımı sınav sorularının, öğretmenlerin ders sürecinde kullandıkları soruların en fazla hatıllama ve anlama basamağında yer aldığının belirlenmesi araştırmanın sonuçlarını destekleyen diğer çalışmalardır.

Öğretmenlerin beşinci sınıf sosyal bilgiler dersi sınavlarında sordukları soruların Yenilenmiş Bloom Taksonomisinin Bilişsel Süreç Boyutunun hangi basamağına karşılık geldiğini belirlemek için yapılan analizler sonucunda, öğretmenlerin sınavlarda genelde olduğu gibi beşinci sınıf düzeyinde de büyük oranda $(\% 57,07)$ hatırlama basamağı ile ilgili sorulara yer verdikleri belirlenmiştir. Beskisiz (2009)'in beşinci sınıf sosyal bilgiler dersinde öğretmenlerin sordukları soruların bilişsel düzeylerinin incelenmesi üzerine yapttğı ve öğretmenlerin yarısından fazlasının hatılama düzeyinde sorular sorduğu sonucu araştırmanın bu sonucunu destekler niteliktedir. Ülkemizde (Akbulut 1999; Çepni ve Azar 1998; Koray ve Yaman, 2002; Mutlu, Uşak ve Aydoğdu, 2003; Sağır, 2003) ve yurt dışında (Harrop ve Swinson, 2003; Stokes ve Milner, 2003) yapılan birçok araştırma sonuçlarına göre öğretmenlerin sordukları soruların çoğunlukla hatırlama düzeyinde olması araştırmanın sonuçlarıyla benzerlik taşımaktadır. Ayrıca araştırma sonucunda elde edilen bulgulara göre öğretmenlerin anlama basamağına karşılık gelen sorulara da yoğun bir şekilde $(\% 39,60)$ yer verdikleri tespit edilmiştir. Taksonominin diğer basamaklarına karşııık gelen sorulara göre dağıııma bakıldığında ise öğretmenlerin sınavlarda çözümleme $(\% 2,72)$, uygulama $(\% 0,54)$ ve değerlendirme $(\% 0,06)$ basamaklarına karşılık gelen sorulara çok az yer verdikleri yaratma basamağına ise hiç yer vermedikleri belirlenmiştir.

Altıncı sınıf sosyal bilgiler dersi sınavlarında öğretmenlerin sordukları soruların Yenilenmiş Bloom Taksonomisinin Bilişsel Süreç Boyutunun hangi basamağına karşlık geldiğini belirlemek amacıyla yapılan analizler neticesinde, öğretmenlerin altnncı sınıf düzeyindeki sınavlarda büyük oranda $(\% 53,25)$ hatırlama basamağı ile ilgili sorulara yer verdikleri belirlenmiştir. Bu durumla ilgili olarak öğretmenlerin sosyal bilgiler derslerini çoğunlukla ezber bilgileri öğretmeye yönelik işledikleri yönünde yorum yapılabilir. Araştırmanın bu sonucu, Demir (2015)'in 2005 yılı sosyal bilgiler öğretim programı üzerine yapmış olduğu araştırmanın sonucuyla çelişirken, Bekaroğlu (2007)'nun altıncı sınıf Türkçe dersi sınav sorularının soru basamaklarına göre incelenmesi üzerine yaptığı araştırmanın sonuçlarıyla örtüşmektedir. Ayrıca araştırmadan elde edilen bulgulara göre öğretmenlerin anlama basamağına karşlık gelen sorulara da yoğun bir şekilde $(\% 39,14)$ yer verdikleri tespit edilmiştir. Taksonominin diğer basamaklarına karşılık gelen sorulara göre dağılıma bakıldığında ise öğretmenlerin sınavlarda uygulama $(\% 4,25)$, çözümleme $(\% 3,2)$ ve değerlendirme $(\% 0,13)$ basamaklarına karşllık gelen sorulara çok az yer verdikleri yaratma basamağına ise hiç yer vermedikleri belirlenmiştir. Bu sonuçlar öğretmenlerin sosyal bilgiler dersi sınav sorularını hazırlarken taksonominin alt bilişsel düzey basamaklarıyla ilgili olan hatırlama ve anlama düzeyindeki sorulara büyük oranda yer verdiklerini göstermektedir. Kaya (2003)'nın sosyal bilgiler öğretmenlerinin "Demokratik Hayat" ünitesi ile ilgili sordukları soruların daha çok alt düzey bilişsel düzeydeki öğrenmeleri ölçecek düzeyde olduğu sonucunun bu araştırmanın sonuçlarıyla benzerlik gösterdiği söylenebilir.

Öğretmenlerin yedinci sınıf sosyal bilgiler dersi sınavlarında sordukları soruların Yenilenmiş Bloom Taksonomisinin Bilişsel Süreç Boyutunun hangi basamağına karşılık geldiğini belirlemek için yapılan analizlere göre, öğretmenlerin yedinci sınıf düzeyinde büyük oranda (\%55) hatırlama basamağı ile ilgili sorulara yer verdikleri belirlenmiştir. Bunun yanında elde edilen bulgulara göre öğretmenlerin anlama basamağına karşılık gelen soruları da yoğun bir şekilde $(\% 37,68)$ kullandıkları tespit edilmiştir. Keray (2012)'ın ilköğretim sekizinci sınıf öğrencilerinin soru sorma becerileri üzerine yapt-

| Kastamonu Eğitim Dergisi, 27(1), 2019| 
ğı çalışmada öğrenci sorularının en fazla hatırlama ve anlama basamağında olduğu sonucuna ulaşması araştırmanın bu sonucunu desteklemektedir, Ayrıca Genç (2006)'in lise öğrencileri, Aydemir ve Çiftçi (2008), Aslan (2011)'ın öğretmen adaylarının soruları üzerine yaptıkları çalışmalarda da araştırmanın bu sonucuna benzer sonuçlar elde edilmiştir. Diğer basamaklara karşılık gelen sorulara göre dağıııma bakıldığında ise öğretmenlerin sınavlarda çözümleme (\%4,25), uygulama $(\% 2,89)$ ve değerlendirme $(\% 0,19)$ basamaklarına karşılık gelen soruları çok az tercih ettikleri yaratma basamağına karşılık gelen soruları ise hiç tercih etmedikleri saptanmıştır.

Araştırma kapsamındaki öğretmenlerin sosyal bilgiler dersi sınavlarında sordukları soruların Yenilenmiş Bloom Taksonomisinin Bilgi Boyutu basamaklarına göre analizi neticesinde, öğretmenlerin olgusal bilgi düzeyinde soruları çok yüksek oranda $(\% 80,38)$ tercih ettikleri belirlenmiştir. Ayrıca öğretmenlerin ikinci olarak ise kavramsal bilgiye karşılık gelen sorulara yer verdikleri, işlemsel ve üst bilişsel boyuta karşılık gelen sorulara ise çok az yer verdikleri tespit edilmiștir. Bu bağlamda öğretmenlerin sınavlarda çoğunlukla alt düzey bilgi boyutundaki sorulara ağırlık verdikleri, üst düzey bilgi boyutundaki sorulara ise çok fazla yer vermedikleri söylenebilir. Gökler (2012)'in İngilizce dersi SBS (Seviye Belirleme Sınavı) ve yazılı sınav sorularını Yenilenmiş Bloom Taksonomisine göre değerlendirdiği çalışmasında soruların çoğunlukla olgusal bilgi boyutunda yani alt düzey basamaklara ait olduğu sonucuna ulaşması araştırmanın bu sonucunu desteklemektedir. Ayrıca Köğçe ve Baki (2009)'nin farklı türdeki liselerin matematik sınavlarında sorulan sorular üzerine yaptığı çalışmada soruların büyük bir kısmının alt bilişsel düzeyde olduğu sonucu bu araştırmanın sonucuyla benzerlik göstermektedir.

Öğretmenlerin beşinci sınıf öğrencilerine uygulamış oldukları sınavlardaki soruların Yenilenmiş Bloom Taksonomisinin Bilgi Boyutu basamaklarına göre dağılımına bakıldığında soruların büyük çoğunluğunun $(\% 89,48)$ olgusal bilgi basamağına denk geldiği görülmektedir. Bununla birlikte öğretmenlerin beşinci sınıf düzeyinde hazırlamış oldukları sınavlardaki sorularda kavramsal ve işlemsel bilgiye karşılık gelen soruları düşük oranda kullandıkları, üst bilişsel bilgi sorularını ise hiç kullanmadıkları sonucuna ulaşı Imıştır.

Sosyal bilgiler öğretmenlerinin altıncı sınıf öğrencilerine uygulamış oldukları sınavlardaki soruların Yenilenmiş Bloom Taksonomisinin Bilgi Boyutu basamaklarına göre dağılımına bakıldığında, soruların büyük çoğunluğunun $(\% 80,25)$ olgusal bilgi basamağına denk geldiği görülmektedir. Ayrıca öğretmenlerin ikinci olarak ise kavramsal bilgiye karşlık gelen sorulara yer verdikleri, işlemsel ve üst bilişsel boyuta karşılık gelen sorulara ise çok az yer verdikleri tespit edilmiştir.

Öğretmenlerin yedinci sınıf öğrencilerine uygulamış oldukları sınavlardaki soruların Yenilenmiş Bloom Taksonomisinin Bilgi Boyutu basamaklarına göre dağılımına bakıldığında soruların oldukça yoğun bir şekilde $(\% 89,48)$ olgusal bilgi basamağına denk geldiği görülmektedir. Bununla birlikte öğretmenlerin yedinci sınıf düzeyinde hazırlamış oldukları sınavlardaki sorularda kavramsal bilgiye beşinci ve altıncı sınıf düzeyine göre daha yüksek oranda $(\% 22,69)$ yer verdikleri, işlemsel bilgi ve üst bilişsel bilgiye karşılık gelen soruları düşük oranda kullandıkları sonucuna ulaşıımıştır.

Araştırma sonuçlarına göre öğretmenlerin sosyal bilgiler derslerinde uyguladıkları sınav sorularının Yenilenmiş Bloom Taksonomisinin Bilişsel Süreç ve Bilgi Boyutundaki alt düzey basamaklara karşılık geldiği saptanmıştr. Willen (1991)'in de ifade ettiği gibi öğretmenler öğrenme-öğretme sürecinde genellikle düşük bilişsel seviyede sorular sormaktadırlar. Öğretmenlerin bilişsel süreç düzeyinde hatılama, bilgi boyutu düzeyinde de olgusal bilgiye karşılık gelen sorulara ağılık vermeleri öğrencilerin üst düzey düşünme becerilerinin gelişmesini sınırlayabildiği gibi bilginin kolayca unutulmasına da yol açabilir.

Öğretmenlerin taksonomideki basamakları bilmesi, sadece alt düzey değil aynı zamanda üst düzey basamaklara karşılık gelen sorular sorabilmesi ve öğretim programına uygun bir süreç planlaması; öğrencilerin bilişsel gelişimlerine katkıda bulunması, eleştirel ve yaratıcı düşünceleri gelişmiş bireyler haline gelmeleri ve kazandıkları bilgi, beceri ve değerleri günlük hayatlarında uygulayabilmeleri yönünde önemlidir. Koray ve Yaman (2002)'a göre eğitimin en alt kademesinden en üst kademesine kadar öğrencilerin üst düzey düşünme becerilerini harekete geçirecek etkinliklerde bulunmak, eğitimin hedefine ulaşması bakımından vazgeçilmez bir unsurudur. Çünkü gerçek manada düşünmeyi, eleştirmeyi ve özgün fikirler ortaya koymayı öğrenen bireyler toplumlarını refah düzeyine eriştirebilirler.

Araştırma sonuçlarından hareketle, sosyal bilgiler öğretmenlerinin sınavlarda Yenilenmiş Bloom Taksonomisinin alt düzey bilişsel ve bilgi boyutu basamaklarının yanı sıra üst düzey bilişsel ve bilgi boyutu basamaklarına karşlık gelen soruları da tercih etmeleri öğrencilerin üst düzey becerilerinin gelişimi açısından önemli olacaktır. Bu doğrultuda, sosyal bilgiler öğretmenlerinin sınavlarda Yenilenmiş Bloom Taksonomisinin alt düzey basamaklarına karşılık gelen sorular sormalarının nedenleri üzerine araştırmalar yapılması önerilmektedir. 


\section{Kaynakça}

Akpınar, E. (2003). Ortaöğretim coğrafya dersleri yazılı sınav sorularının bilişsel düzeyleri. Erzincan Eğitim Fakültesi Dergisi, 5 (1), $13-21$. Akpınar, E. ve Ergin, Ö. (2006). Fen Bilgisi Öğretmenlerinin Yazılı Sınav Sorularının Değerlendirilmesi. Milli Eğitim Dergisi, Sayı: 172 Güz, $225-231$. Amer, A. (2006). Reflections on bloom's revised taxonomy. electronic journal of research in educational psychology, 4 (8), $213-220$.

Anderson, L.W. (Ed.), Krathwohl, D.R.(Ed.), Airasian, P.W., Cruikshank, K.A., Mayer, R.E., Pintrich, P.R., Raths, J., \& Wittrock, M.C. (2001). Öğrenme, Öğretim ve Değerlendirme ile İlgili Bir Sınıflama: Bloom'un Eğitimin Hedefleri İle illgili Sınıflamasının Güncelleştirilmiş Biçimi. (Çeviri: D. A, Özçelik 2010.). Ankara: Pegem A Yayıncılık.

Arıkan, R. (2011). Araştırma Yöntem ve Teknikleri. (Geliştirilmiş İkinci Baskı). Ankara: Nobel Akademik Yayıncılık.

Aslan, C. (2011). Soru sorma becerilerini geliştirmeye dönük öğretim uygulamalarının öğretmen adaylarının soru oluşturma becerilerine etkisi. Eğitim ve Bilim Dergisi, 36 (160), 236-249.

Aydemir, Y. ve Çiftçi, Ö. (2008). Edebiyat öğretmen adaylarının soru sorma becerileri üzerine bir araştırma. Yüzüncü Yı Üniversitesi Eğitim Fakültesi Dergisi, 5 (2), 103-115.

Ayvacı, H. Ş. ve Türkdoğan, A. (2010). Yeniden yapılandırılan bloom taksonomisine göre fen ve teknoloji dersi yazılı sorularının incelenmesi. Türk Fen Eğitimi Dergisi, 7 (1), 13-25.

Bailey, K. (1987). Methods of Social Research. (Üçüncü Baskı), New York: The Free Press. London-. Collier Macmillan Publishers.

Balta, A. (2006) ilköğretim okullarında uygulanan sınavlarda tam öğrenmenin (bloom taksonomisi) kullanımının önemi. Yayınlanmamış yüksek lisans tezi. Yeditepe Üniversitesi Sosyal Bilimler Enstitüsü, İstanbul.

Baysen, E. (2006). Öğretmenlerin sınıfta sordukları sorular ile öğrencilerin bu sorulara verdikleri cevapların düzeyleri. Kastamonu Eğitim Dergisi, 14 (1), 21-28.

Beskisiz, E. (2009). Beşinci sınıf öğretmenlerinin öğrenme stillerine göre sosyal bilgiler dersinde sordukları soru türleri ve bilişsel düzeylerinin incelenmesi. Yayınlanmamış yüksek lisans tezi, Çukurova Üniversitesi, Sosyal Bilimler Enstitüsü, Adana

Bloom, B. S. (1956). Taxonomy of Educational Objectives. the Classification of Educational Goals, Handbook 1: The Cognitive Domain. New York: David McKay Company Inc.

Büyükalan, F. S. (2007). Soru Sorma Sanatı. (ikinci Baskı). Ankara: Nobel Yayın Dağıtım.

Can, R. (2006). Türk dili ve edebiyat öğretmenlerinin soru sorma becerileri üzerine bir alan araştırması. Yayımlanmamış yüksek lisans tezi, Gazi Üniversitesi, Eğitim Bilimleri Enstitüsü Ankara.

Celilova, V. (2006). Genel liselerin ikinci sınıflarında okutulan türk edebiyat ders kitaplarındaki metin altı soruları üzerine bir inceleme. Yayınlanmamış yüksek lisans tezi. Gazi Üniversitesi Eğitim Bilimleri Enstitüsü, Ankara.

Çalışkan, H. (2011). Öğretmenlerin hazırladığı sosyal bilgiler dersi sınav sorularının değerlendirilmesi. Eğitim ve Bilim Dergisi, 36 (160), $120-132$.

Çepni, S. ve Azar, A. (23-25 Eylül 1998) Lise fizik sınavlarında sorulan soruların analizi. III. Ulusal Fen Bilimleri Eğitimi Sempozyumu. Karadeniz Teknik Üniversitesi Trabzon, 109-114.

Çepni. S., Özsevgeç, T. ve Gökdere, M. (2003). Bilişsel gelişim ve formal operasyon dönem özelliklerine göre ÖSS fizik ve lise fizik sorularının incelenmesi. Milli Eğitim Dergisi, 157, 30-39.

Çolak, K. ve Demircioğlu, í. H. (2010). Tarih dersi sınav sorularının bloom taksonomisi'nin bilişsel alan düzeyi açısından sınıflandıııması. Millî Eğitim Dergisi, 187, 160-171.

Davis, O. L., Jr., and Tinsley, D. C. (1967). Cognitive objectives revealed by classroom questions asked by social studies student teachers. Peabody Journal of Education, 45, 21-26

Davis, O. L., Morse, K. R., Rogers, V. M. \& Tinsley, D. C. (1969). Studying the cognitive emphases of teachers' classroom questions. educational leadership. 26 (7), 711-719.

Demir, P. (2015). Yenilenmiş bloom taksonomisine göre 2005 yılı sosyal bilgiler öğretim programında yer alan kazanımlar ve seviye belirleme sınav soruları. Yayınlanmamış yüksek lisans tezi. Ondokuz Mayıs Üniversitesi Eğitim Bilimleri Enstitüsü, Samsun. Durukan, E. (2009). 7. sınıf türkçe ders kitaplarındaki metinleri anlamaya yönelik sorular üzerine taksonomik bir inceleme. Millî Eğitim Dergisi, 181, 84-93.

Erdem, E. ve Demirel, Ö. (2002). Program geliştirmede yapılandırmacılık yaklaşımı. Hacettepe Üniversitesi Eğitim Fakültesi Dergisi, $23,81-87$.

Genç, A. (2006), Ortaöğretim coğrafya derslerinde öğrencilerin soru sorma becerilerinin değerlendirilmesi. Yayınlanmamış yüksek lisans tezi. Gazi Üniversitesi Ĕgitim Bilimleri Enstitüsü, Ankara.

Gökler, Z. S. (2012). İlköğretim ingilizce ders hedefleri kazanımları sbs soruları ve yazılı sınav sorularının yeni bloom taksonomisine göre değerlendirilmesi. Yayınlanmamış yüksek lisans tezi. Osmangazi Üniversitesi Eğitim Bilimleri Enstitüsü, Eskişehir.

Harrop, A., Swinson, J. (2003). Teacher's questions in the infant, junior and secondary school, Educational Studies, 29 (1), $49-57$.

İşçil, N. (1973). İstatistik Metodları ve Uygulamaları, Ankara: AITIA Yayınları.

İşman, A. (2000). Eğitimde Planlama ve Değerlendirme. Adapazarı: Değişim Yayınları.

Kaptan, F. (1999). Fen Bilgisi Öğretimi. İstanbul: Milli Eğitim Basımevi.

| Kastamonu Eğitim Dergisi, 27(1), 2019| 
Karadüz, A. (2009). Türk dili ve edebiyat eğitiminin hedefler kapsamında ölçme ve değerlendirmede kullanılan soru nitelikleri. Erciyes Üniversitesi Sosyal Bilimler Enstitüsü Dergisi, 27, 17-31.

Kasar, N. (2013). Matematik Derslerinde Alternatif Çözüm Yollarına ve Farklı Soru Türlerine Ne Ölçüde Yer Verilmektedir?: Sınıf lçi Uygulamalardan Örnekler. Yayınlanmamış yüksek lisans tezi. Gaziantep Üniversitesi, Eğitim Bilimleri Enstitüsü.

Kaya, N. (2003). 6. sınıf demokratik hayat ünitesinde sosyal bilgiler öğretmenlerinin hazırladıkları yazılı sınav sorularının kapsam geçerliği ve taksonomik boyutunun incelenmesi. Yayınlanmamış yüksek lisans tezi. Karadeniz Teknik Üniversitesi, Sosyal Bilimler Enstitüsü, Trabzon.

Khan, W. B., Inamullah, H. M. (2011). A study of lower-order and higher-order questions at secondary level. Asian Social Science, 7 (9), $149-157$.

Kılıç, D. (2010). Sosyal bilgiler öğretmenlerinin tarih konuları ile ilgili soru sorma becerilerinin bloom taksonomisine göre değerlendirilmesi. Yayınlanmamış yüksek lisans tezi. Marmara Üniversitesi Eğitim Bilimleri Enstitüsü, İstanbul.

Kılıç, P. (2012). Sınıf ve İlköğretim Matematik Öğretmenlerinin Tercih Ettikleri Soru Türlerinin Incelenmesi. Yayınlanmamış yüksek lisans tezi. Gaziantep Üniversitesi Sosyal Bilimler Enstitüsü.

Koray, Ö. \& Yaman, S. (2002). Fen bilgisi öğretmen adaylarının soru sorma becerilerinin bloom taksonomisine göre değerlendirilmesi. Gazi Üniversitesi Eğitim Fakültesi Dergisi, 10 (2), 317-324.

Köğçe, D. ve Baki, A. (2009). Matematik öğretmenlerinin yazılı sınav soruları ile öss sınavlarında sorulan matematik sorularının bloom taksonomisine göre karşılaştrııması. Pamukkale Üniversitesi Eğitim Fakültesi Dergisi, 26, 70-80.

Krathwohl, D. R. (2002). A revision of bloom's taxonomy: an overview. Theory Into Practice, 41 (4), 212-218.

Linn, R.L. and Gronlund, N.E. (1995). Measurement and Assessment in Teaching. (Seventh Edition). Upper Saddle River, New Jersey, Prentice Hall. Lipscomb, J.W. (2001). Is bloom's taxonomy better than Intuitive judgement for classifying test questions? Education, 106 (1), $102-108$. Merriam, S. (2013). Nitel araştırma: Desen ve Uygulama Iç̧in Bir Rehber. S. Turan (çeviri editörü). Ankara: Nobel Akademik Yayıncılık.

Miles, M, B., \& Huberman, A. M. (1994). Qualitative data analysis: An expanded Sourcebook. (2nd ed). Thousand Oaks, CA: Sage.

Özden, Y. (2005). Öğrenme ve Öğretme. Ankara: Pegem A Yayıncılık.

Patton, M.Q. (2002). Qualitative research and evaluation methods (3rd Ed.). London: Sage Publications, Inc.

Poggenpoel, M., \& Myburgh, C. (2003). The researcher as research instrument in educational research: A: Research instrument. Education, $124,418-421$.

Sağır, D. (2003), Ortaöğretim lise 1. sınıf coğrafya dersi müfredat programında yer alan yeryüzünün biçimlenmesi (dış kuvvetler) ünitesinde öğretmenlerin öğrencileri değerlendirmede bloom'un taksonomisini kullanma düzeyleri üzerine bir araştrrma (Eskişehir ili örneği). Yayınlanmamış yüksek lisans tezi. Gazi Üniversitesi Eğitim Bilimleri Enstitüsü.

Savage, L. B. (1998). Eliciting Critical Thinking Skills Through Questioning. Clearing House, 71 (5), 291-293.

Taymaz, H. (1975). Ortaöğretimde Öğrencinin Ölçülmesi ve Değerlendirilmesi. Ankara: MEB Yayınları.

Ün Açıkgöz, K. (2003). Aktif Öğrenme. İzmir: Eğitim Dünyası Yayınları.

Willen, W. (1991). Questioning Skills For Teachers. What Research Say to The Teacher? , (Third Edition). Washington, D.C.: National Education Association. ERIC Document Reproduction (ED 332983).

Yalın, H. İ. (2005). Öğretim Teknolojileri ve Materyal Geliştirme. (On Beşinci Baskı). Ankara: Nobel Yayın Dağıtım.

Yıldııım A., Şimşek, H. (2011). Sosyal Bilimlerde Nitel Araştırma Yöntemleri (Sekizinci Baskı). Ankara: Seçkin Yayıncılık. 


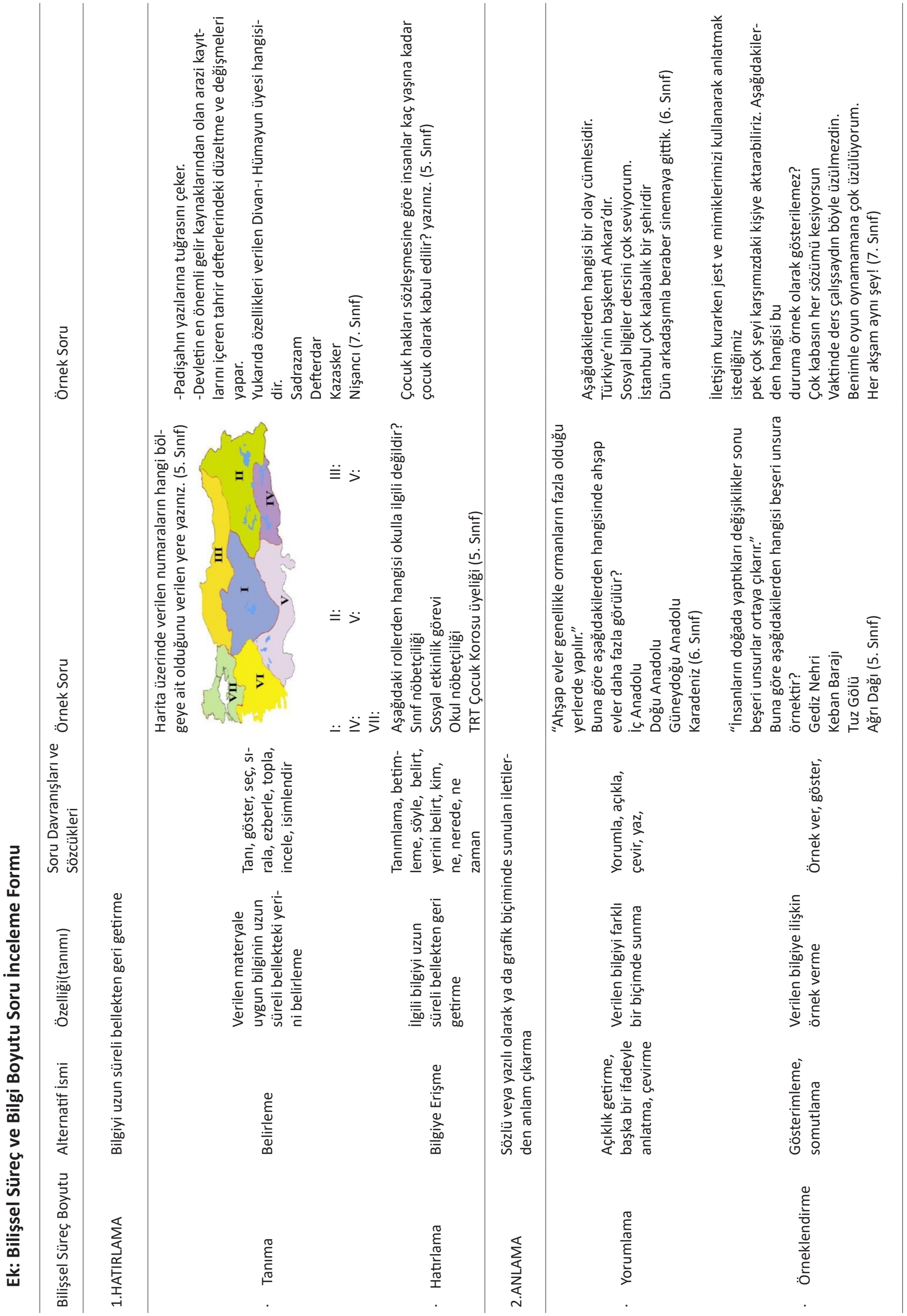




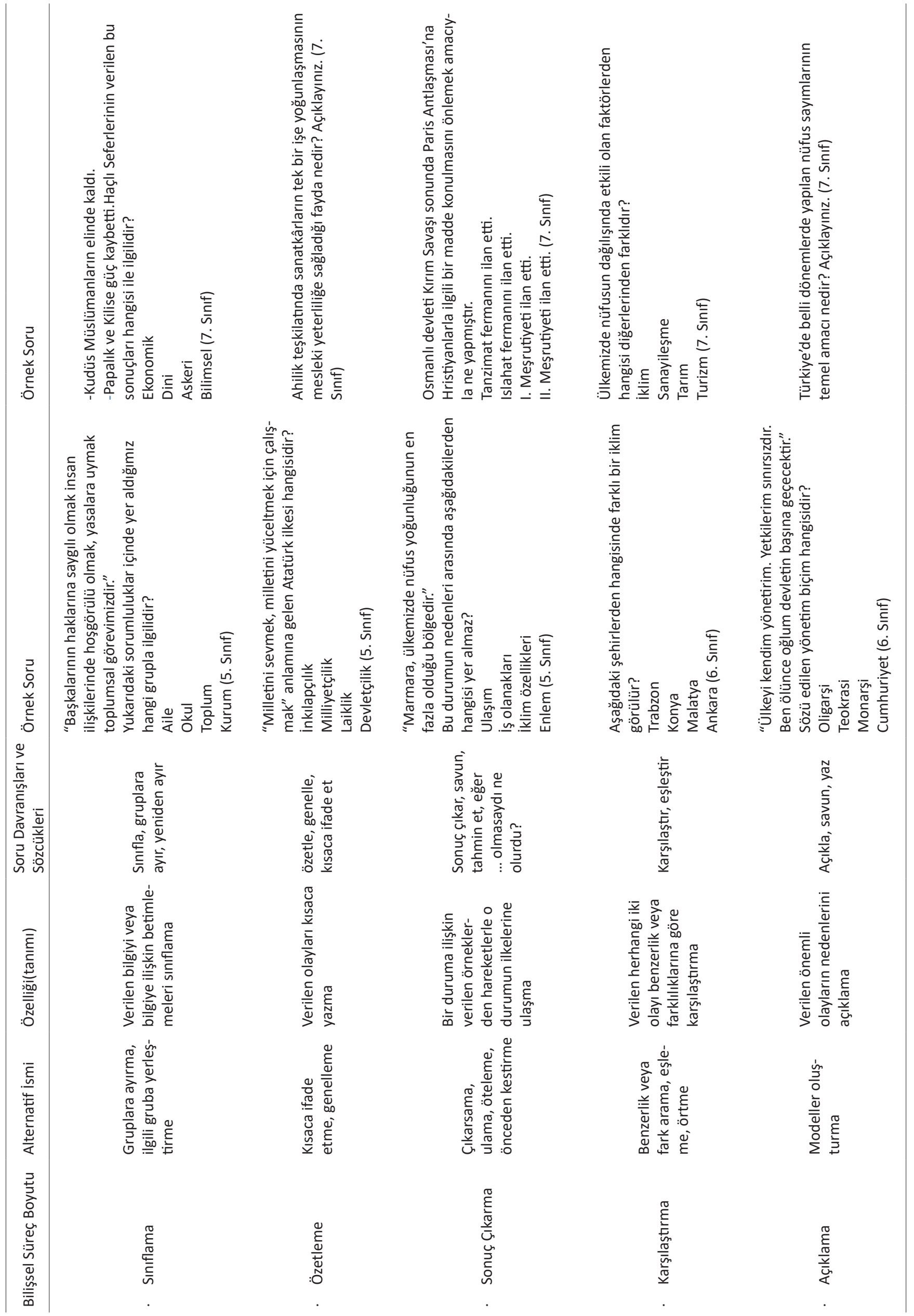




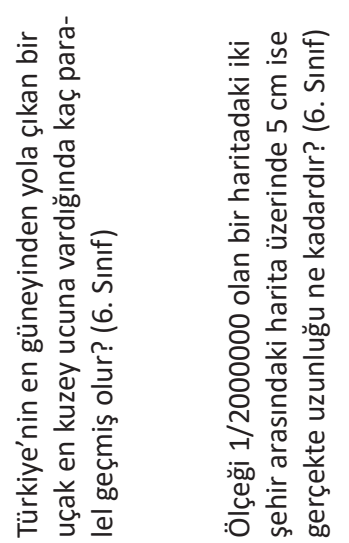

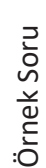

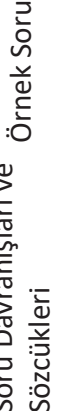

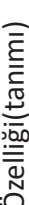

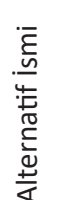

产

崩

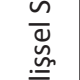

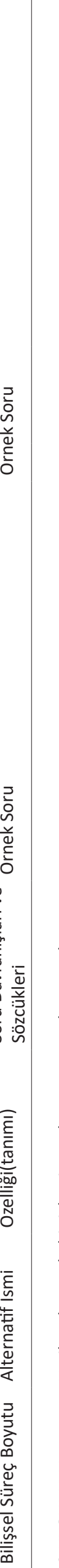

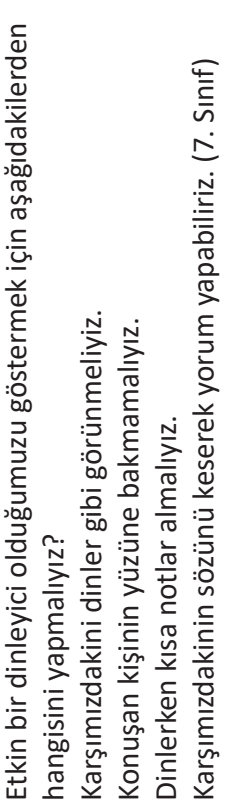

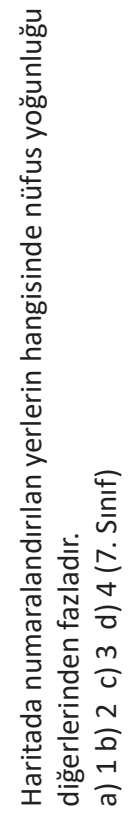

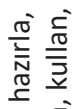

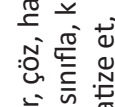

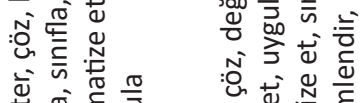

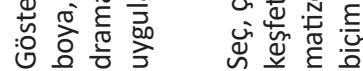

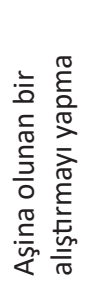

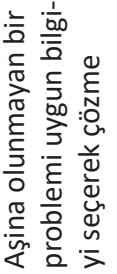

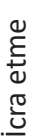

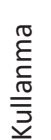

$\frac{\sqrt{2}}{\frac{2}{0}}$

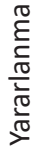

$\frac{\pi}{\frac{\pi}{80}}$

:

는

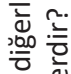

들

迹

?气

紊

急

응

这

产竞

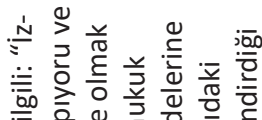

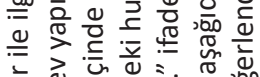

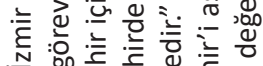

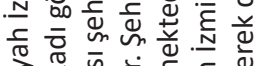

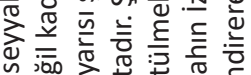

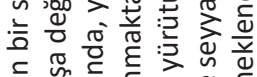

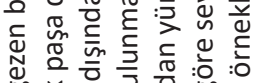

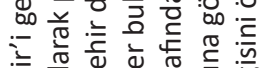

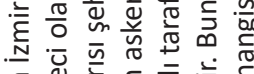

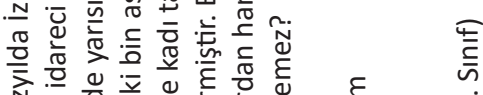

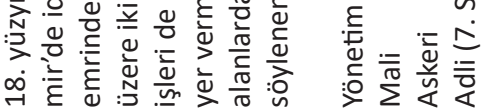

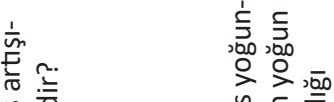

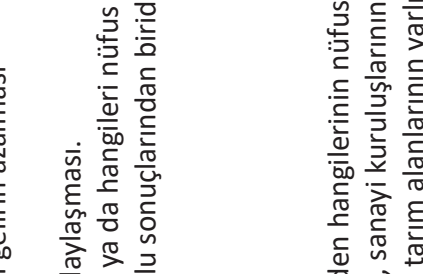

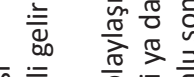

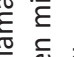

然

政

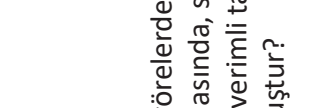

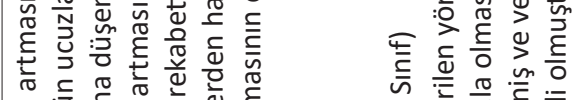

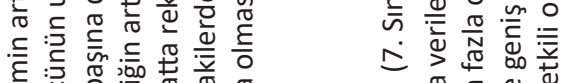

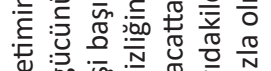

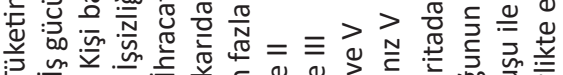

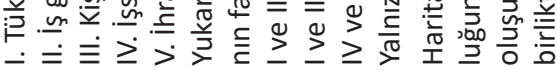

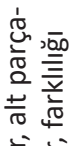

言蓄

边商

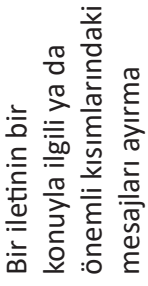

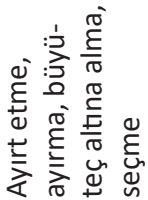

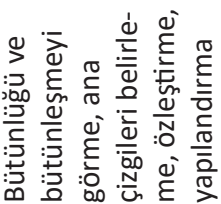

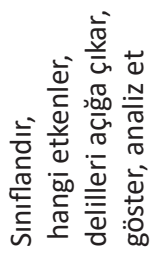

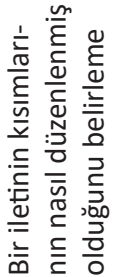

능 드응

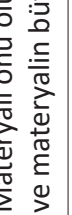

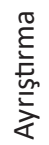

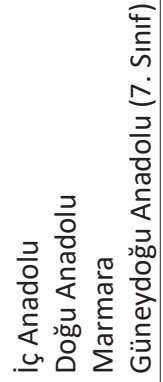

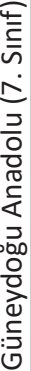
| 


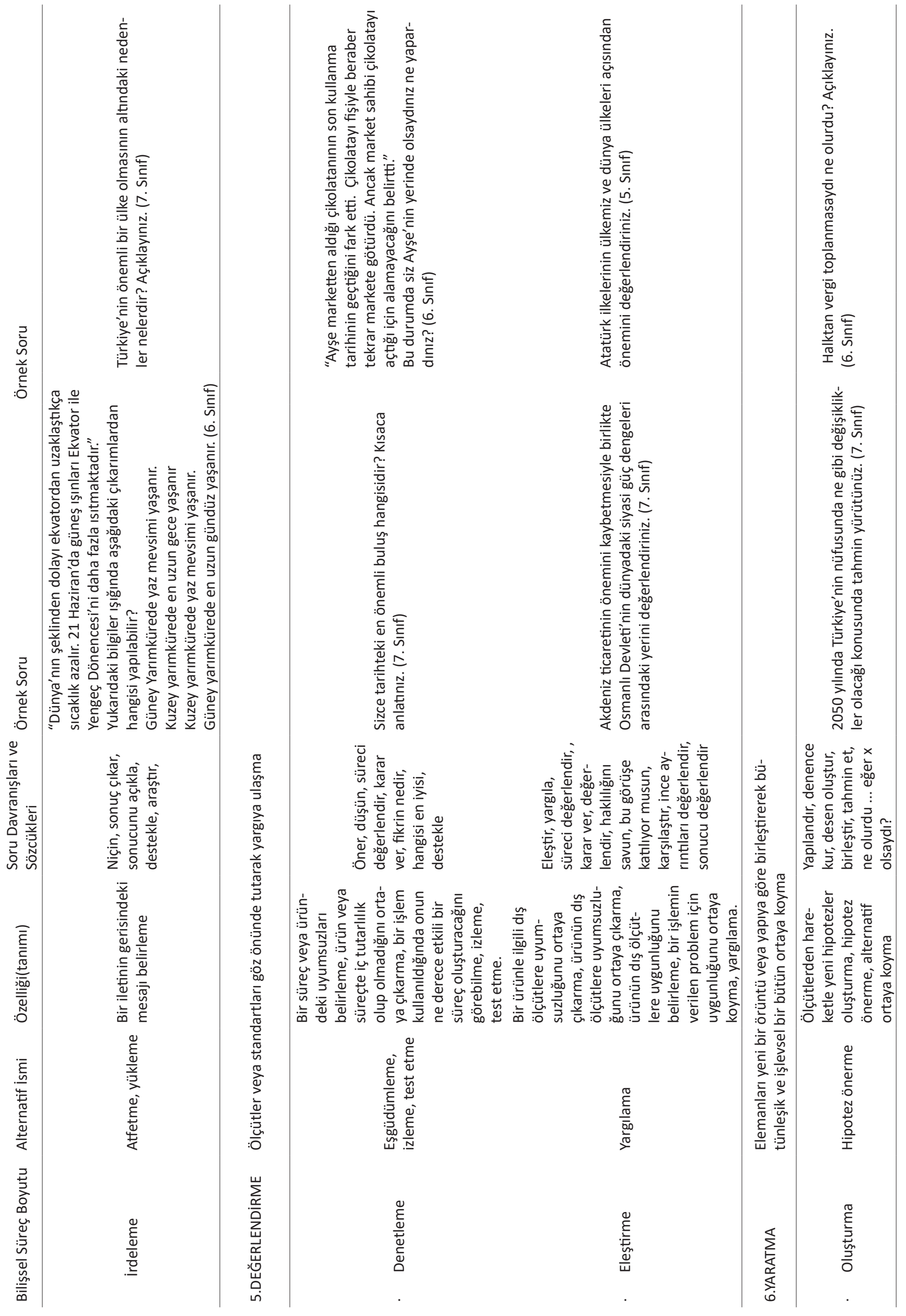




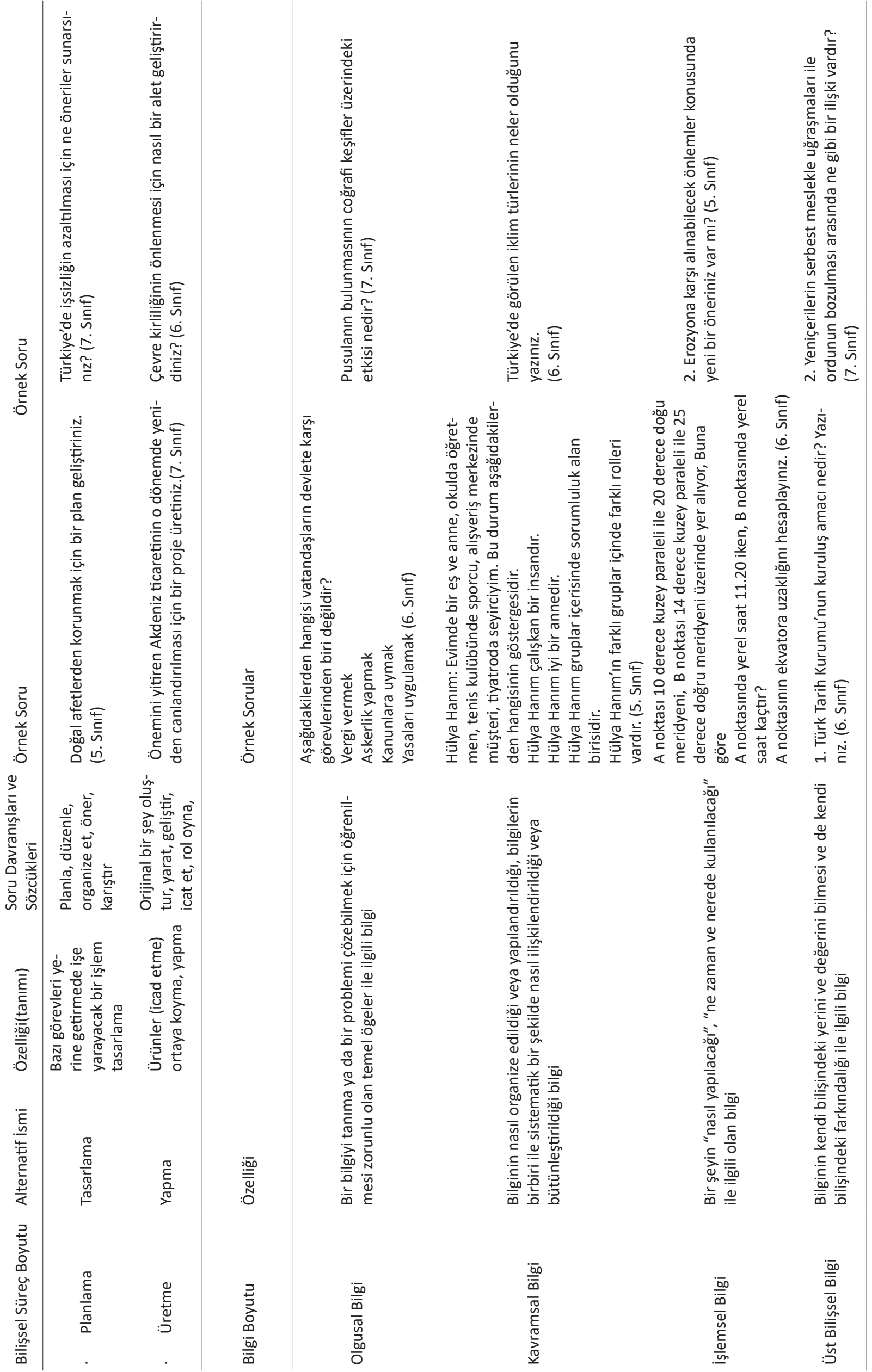

